\title{
Faktor-Faktor yang Memengaruhi Jumlah Anak di Desa Pusong Kecamatan Banda Sakti Kota Lhokseumawe
}

\section{Factors That Influence The Numbers of Children in The Village Pusong Banda Sakti Lhokseumawe City}

\author{
Rika Mursyida**1, Erna Mutiara ${ }^{2}$, Asfriyati $^{3}$ \\ ${ }^{1}$ Dosen STIKES Bumi Persada Lhokseumawe \\ ${ }^{2,3}$ Staf Pengajar Ilmu Kesehatan Masyarakat USU-Medan \\ *Korespondensi Penulis: rikamursyida@ymail.com
}

\begin{abstract}
Abstrak
Jumlah anak adalah banyaknya hitungan anak yang dimiliki, biasanya dalam bentuk besar keluarga yang diinginkan. Besar keluarga akan meningkat seiring dengan peningkatan jumlah anak, karena setiap keluarga berupaya untuk mencapai jumlah anak dengan cara tersendiri. Penelitian ini bertujuan untuk mengetahui faktor yang memengaruhi jumlah anak yaitu faktor usia istri, pendapatan keluarga, nilai anak melalui umur pertama melakukan hubungan seksual terhadap jumlah anak didesa pusong kecamatan banda sakti kota lhokseumawe tahun 2017. Jenis penelitian adalah penelitian observasional dengan pendekatan potong lintang. Populasi adalah seluruh istri Pasangan Usia Subur (PUS) yang bertempat tinggal didesa pusong kecamatan Banda Sakti Kota Lhokseumawe pada bulan januari 2017 sebanyak 246 orang. Sampel berjumlah 95 orang yang dilakukan secara acak sederhana menggunakan tabel acak. Analisis data menggunakan analisis jalur (Path Analysis). Hasil penelitian menunjukkan besaran pengaruh secara simultan usia istri, pendapatan keluarga, nilai anak dan umur pertama melakukan hubugan seksual terhadap jumlah anak sebesar 24,9\%. Dari tiga variabel sebagai variabel bebas maka variabel umur pertama melakukan hubugan seksual yang berpengaruh terhadap jumlah anak $(p=<0,001)$ dengan besaran pengaruh $24,9 \%$ dan sisanya $75,1 \%$ dipengaruhi oleh faktor lain seperti $\mathrm{KB}$, pendidikan dan pekerjaan ibu. Disarankan kepada tokoh masyarakat da tokoh agama Desa Pusong Kota Lhokseumawe sebagai ketua "tuha peut gampong" agar dapat meluruskan pemahaman negatif tentang alat kontrasepsi sehingga masyarakat yakin bahwa kontrasepsi halal/dapat digunakan oleh istri pasangan usia subur guna mengatur jumlah anak.
\end{abstract}

Kata kunci: usia istri, pendapatan keluarga, nilai anak melalui umur pertama melakukan hubungan seksual, jumlah anak.

\section{Abstract}

The number of children means how many children owned by someone, usually in the form of the intended family size. Family size will be increased, along with the increase in the number of children because each family attempts to get the number of children by their own way. The objective of the research was to find out some factors influenced the number of children such as the factors of mother's age, family income, and child value through the first age at exposure to sexual intercourse at Pusong Village, Banda Sakti Subdistrict, City of Lhokseumawe, in 2017. The research was observational with cross sectional design. The population was 246 wives of PUS (Fertile Age Couple) at Pusong Village, in January, 2017, 
and 95 of them were used as the samples, using simple random sampling technique. The data were analyzed by using path analysis. The result of the research showed that simultaneously wife's age, family income, child value, and the first age at exposure to sexual intercourse influenced the number of children of 24.9\%. Of the three independent variables, the variable of the first age at exposure to sexual intercourse influenced the number of children ( $p<$ $0.001)$ with the amount of influence was $24.9 \%$, and the rest $(75.1 \%)$ was influenced by other factors such as Family Planning, education, and mother's job. It is recommended that community and religious leader at Pusong Village, as the head of "tuha peut gampong' should correct negative perception about the use of contraception device so that the community will believe that contraception device is halal (legitimate) and can be used by the wives of fertile age couple arranging their number of children.

Keywords: Wife's Age, Family Income, Child value, The First Age at Exposure to Sexual Intercourse, Number of Children

\section{PENDAHULUAN}

Provinsi Nanggroe Aceh Darussalam yang merupakan bagian dari negara Indonesia memiliki jumlah penduduk yaitu 4.597.308 orang dimana jumlah laki-laki yaitu 2.300.442 orang sedangkan perempuan berjumlah 2.296 .866 orang terdapat 20,4 \% diantaranya adalah anak - anak yaitu 938.300 orang (Dinkes Aceh, 2016).

Berdasarkan hasil pencacahan Sensus Penduduk 2010, jumlah penduduk kota Lhokseumawe sementara adalah 170.504 orang, yang terdiri atas 84.893 laki-laki dan 85.611 perempuan. Dalam hasil Sensus Penduduk tahun 2010 tersebut tampak bahwa penyebaran penduduk Lhokseumawe masih bertumpu di Kecamatan Banda Sakti yakni 42,92\%, dimana di Desa Pusong merupakan bagian dari kecamatan ini yang memiliki jumlah penduduk 1175 KK, dengan jumlah anak 347 orang tahun 2014, meningkat menjadi 354 orang anak pada tahun 2015 dan 367 orang anak pada tahun 2016 (Badan Pusat Statistik, BkkbN, Depkes RI, Macro International, 2016).

Hasil survei awal yang dilakukan di Desa Pusong Kecamatan Banda Sakti Kota Lhokseumawe terhadap 10 orang ibu yang sudah menikah dan mempunyai anak, jumlah anak yang mereka miliki $2-7$ orang anak. Ketika ditanya alasannya memiliki anak banyak karena bagi mereka mempunyai anak banyak akan memiliki banyak rezeki, anak juga menjadi tenaga kerja tambahan dalam memenuhi kebutuhan keluarga, dengan rata - rata ibu berpendidikan dasar sehingga sulit menerima informasi tentang KB dan menganggap KB itu tidak boleh dalam agama sehingga mereka cenderung menambah jumlah anak 2 sampai 3 orang anak lagi karena meyakini anak bisa mencari upah sendiri untuk memenuhi kebutuhannya sehingga tidak menjadi beban keluarga. Namun ada juga keluarga yang 
memiliki anak pada jumlah 2 orang saja, dikarenakan faktor kesehatan ibu yang tidak mampu melanjutkan penambahan jumlah anak karena sudah melakukan sterilisasi.

Pendapatan keluarga di Pusong mayoritas rendah cukup untuk kebutuhan pokok saja namun jumlah anak tidak menjadi masalah bagi mereka karena semakin banyak jumlah anak semakin banyak yang menopang ekonomi keluarga. Sedangkan pada 4 orang (26,7 persen) ibu yang berusia diatas 35 tahun dan memiliki anak >2 orang mengatakan tidak akan membatasi jumlah anak hanya saja akan merencanakan jarak kehamilannya, walaupun ratarata anak hanya mampu disekolahkan sampai selesai SD dan SMP karena keterbatasan ekonomi yang selanjutnya mengikuti kebiasaan pekerjaan ayah dan ibunya sebagai nelayan dan penjemur ikan. Orang tua menganggap kebutuhan anak hanya pokok saja sementara kasih sayang, kebahagiaan, penghargaan, rekreasi, sama sekali tidak diperhatikan.

Selanjutnya Desa Pusong juga merupakan bagian dari Kecamatan Banda Sakti Kota Lhokseumawe yang berkawasan padat penduduk dan berpemukiman kumuh dengan mata pencaharian 95\% adalah nelayan dan penjemur ikan, dengan keadaan sosial ekonomi yang rendah memiliki banyak anak merupakan sumber infestasi yang dapat membantu meringankan beban finansial keluarga, setiap anak memiliki rezekinya masing - masing, berapapun jumlah anak mereka beranggapan anak adalah rezeki yang harus disyukuri serta pemahaman bahwa setiap keluarga harus memiliki anak laki - laki sebagai garis keturunan yang melanjutkan gelar "Teungku, Sayed, Ampon" dari garis keturunan orang tua laki - laki. Apabila tidak memiliki anak laki - laki maka gelar keturunan tersebut putus dan berakhir pada anak perempuan dengan gelar keturunan "cut". Keadaan ini merupakan keyakinan budaya yang memengaruhi jumlah anak dalam sebuah keluarga.

Diana (2007) dalam Siregar (2011) mengatakan setiap keluarga perlu mengukur berbagai faktor yang memengaruhi jumlah anak. Dari aspek sosial, kesehatan, finansial hingga adat dan budaya. Dari sisi finansial, sebuah keluarga dapat mengukur kemampuan pendapatan yang dikomparasikan dengan rencana pendidikan serta biaya pemenuhan kebutuhan dan kesehatan bagi anak yang akan dilahirkan. Anak yang direncanakan hendaknya memiliki kualitas pendidikan dan kehidupan yang terjamin. Dari sisi sosial, jumlah anak dapat disesuaikan dengan kondisi sosial masyarakat, keluarga, dan berbagai faktor psikologis. Mulai dari keinginan pribadi, kemampuan membagi waktu untuk anak, hingga daya dukung lingkungan yang baik bagi tumbuh kembang anak. 
Berdasarkan hasil penelitian Muchtar dan Purnomo (2009), wanita yang bekerja mempunyai fertilitas sedikit lebih tinggi dibanding wanita yang tidak bekerja (2,5 dibanding 2,3 anak), dan pengaruh pekerjaan terhadap fertilitas signifikan ( $\mathrm{p}<0,05)$. Bila dilihat menurut kelompok jumlah anak lahir hidup menunjukkan bahwa umumnya wanitayang bekerja mempunyai jumlah anak lahir hidup 3 anak atau lebih, sedangkan wanita yang tidak bekerja umumnya belum mempunyai anak dan mempunyai antara 1-2 anak.

Selanjutnya menurut Muchtar dan Purnomo (2009), umur kumpul pertama sangat berkaitan dengan tingkat fertilitas, karena umur kumpul pertama menandakan dimulainya masa reproduksi wanita. Oleh karena itu semakin muda wanita mulai aktif secara seksual, maka semakin panjang masa reproduksinya, dan pada akhirnya makin besar pula kemungkinan mempunyai anak yang banyak. Umur kumpul pertama dikelompokkan menjadi, $\leq 15$ tahun, 16-17 tahun, 18-19 tahun, 20-29 tahun, dan 30+ tahun.

Berdasarkan uraian tentang faktor - faktor yang memengaruhi jumlah anak di atas dan hasil survei pendahuluan yang telah dilakukan, maka dirasa perlu dilakukan penelitian tentang faktor - faktor apa saja yang memengaruhi jumlah anak di Desa Pusong Kecamatan Banda Sakti Kota Lhokseumawe Tahun 2017.

Tujuan penelitian adalah untuk mengetahui faktor yang memengaruhi jumlah anak yaitu umur istri, pendapatan keluarga dan nilai anak melalui umur pertama melakukan hubungan seksual terhadap jumlah anak di Desa Pusong Kecamatan Banda Sakti Kota Lhokseumawe Tahun 2017.

\section{METODE PENELITIAN}

Jenis penelitian adalah observasional dengan pendekatan potong lintang (cross sectional). Lokasi dalam penelitian di Desa Pusong Kecamatan Banda Sakti Kota Lhokseumawe. Populasi dalam penelitian ini adalah seluruh istri PUS yang bertempat tinggal di Desa Pusong Kecamatan Banda Sakti Kota Lhokseumawe pada bulan Januari 2017 sebanyak 246 orang. Besar sampel adalah 95 orang. Penarikan sampel dilakukan secara Simple Random Sampling (pengambilan sampel secara acak sederhana), menggunakan tabel acak C-Survey sampai memenuhi besar sampel yang diinginkan. Variabel yang diukur adalah umur istri, pendapatan keluarga, nilai anak, umur pertama melakukan hubungan seksual dan jumlah anak. Analisis data yang digunakan adalah Path Analysis (analisis jalur). 


\section{HASIL DAN PEMBAHASAN}

Tabel 1. Distribusi Karakteristik Istri PUS

\begin{tabular}{lcc}
\hline \multicolumn{1}{c}{ Karakteristik } & N & \% \\
\hline Agama & 95 & 100,0 \\
Islam & & \\
Pendidikan & 84 & 88,4 \\
Rendah & 11 & 11,6 \\
Tinggi & & \\
Pekerjaan & 4 & 4,2 \\
Buruh & 5 & 5,3 \\
PNS & 55 & 57,9 \\
Ibu rumah tangga & 14 & 14,7 \\
Pedagang & 17 & 17,9 \\
Wiraswasta & & \\
Suku & 77 & 81,1 \\
Aceh & 7 & 7,4 \\
Jawa & 8 & 8,4 \\
Padang & 1 & 1,1 \\
Batak & 2 & 2,1 \\
Melayu & & \\
\hline
\end{tabular}

Pada penelitian ini, karakteristik istri yang dilihat meliputi agama, pendidikan, pekerjaan dan suku istri PUS berjumlah 95 orang di Desa Pusong Kecamatan Banda Sakti Kota Lhokseumawe Tahun 2017. Tabel 4.2 menunjukkan bahwa semua istri beragama Islam sebesar $100 \%$, lebih banyak istri berpendidikan rendah sebesar $88,4 \%$ dengan pekerjaan sebagai ibu rumah tangga sebesar 57,9\% yaitu membantu jemuran ikan dan istri di Desa Pusong lebih banyak bersuku Aceh sebesar 81,1\%.

Tabel 2. Gambaran Usia Istri, Pendapatan Keluarga, Nilai Anak, Umur Pertama Melakukan Hubungan Seksual, dan Jumlah Anak

\begin{tabular}{lcccccc}
\hline \multicolumn{1}{c}{ Variabel } & Mean & SD & Min & Max & 95\% CI & n \\
\hline Usia Istri (tahun) & 34,40 & 6,49 & 22 & 45 & 33,$08 ; 35,72$ & 95 \\
Pendapatan & 2707368,4 & 573203,4 & 2000000 & 4000000 & 2590600,$92 ; 2824135,92$ & 95 \\
Keluarga (Rp) & 2 & 1 & & & & \\
Nilai Anak & 25,82 & 3,71 & 15 & 32 & 25,$07 ; 26,58$ & 95 \\
Umur pertama & 21,01 & 2,15 & 18 & 26 & 20,$57 ; 21,45$ & 95 \\
melakukan & & & & & & \\
hubungan seksual & & & & & & \\
(tahun) & & & & & & \\
\hline Jumlah Anak & 3,02 & 1,48 & 0 & 6 & 2,$72 ; 3,32$ & 95 \\
\hline
\end{tabular}


Rata-rata usia istri (tahun) di Desa Pusong Kecamatan Banda Sakti Kota Lhokseumawe adalah 34,40 dan nilai SD 6,49. Rata-rata pendapatan keluarga (Rp) di Desa Pusong Kecamatan Banda Sakti Kota Lhokseumawe adalah Rp 2707368,42 dan nilai SD Rp 573203,41. Rata-rata nilai anak di Desa Pusong Kecamatan Banda Sakti Kota Lhokseumawe adalah skor 25,82 dan nilai skor SD 3,71. Rata-rata umur pertama melakukan hubungan seksual (tahun) di Desa Pusong Kecamatan Banda Sakti Kota Lhokseumawe saat menikah adalah 21,01 dan SD 2,15. Rata-rata jumlah anak di Desa Pusong Kecamatan Banda Sakti Kota adalah 3,02 orang dan nilai SD 1,48 orang.

Tabel 3. Hubungan Usia Istri, Pendapatan Keluarga, Nilai Anak, Umur Pertama Melakukan Hubungan Seksual dengan Jumlah Anak

\begin{tabular}{llcc}
\hline \multicolumn{1}{c}{ Variabel 1 } & \multicolumn{1}{c}{ Variabel 2 } & P & r \\
\hline Usia istri & Pendapatan & 0,001 & 0,333 \\
& Nilai anak & 0,832 & 0,022 \\
& Umur pertama melakukan & 0,500 & 0,070 \\
& hubungan seksual & & \\
& Jumlah anak & $<0,001$ & 0,703 \\
Pendapatan & Nilai anak & 0,479 & $-0,073$ \\
& Umur pertama melakukan & 0,039 & 0,213 \\
& hubungan seksual & & \\
Nilai anak & Jumlah anak & 0,016 & 0,247 \\
& Umur pertama melakukan & 0,028 & $-0,226$ \\
hubungan seksual & & \\
Umur pertama & Jumlah anak & 0,061 & 0,193 \\
melakukan hubungan & Jumlah anak & 0,031 & $-0,221$ \\
\hline
\end{tabular}

Pada hasil penelitian diperoleh bahwa usia istri berhubungan dengan pendapatan $(\mathrm{p}=0,001)$ dan $\mathrm{r}=0,333$ artinya usia istri berkorelasi lemah $(\mathrm{r}<0,5)$, sedangkan jumlah anak $(\mathrm{p}<0,001)$ dan $\mathrm{r}=0,703$ artinya usia istri berkorelasi kuat terhadap jumlah anak $(r>0,5)$.

Pendapatan berhubungan dengan umur pertama melakukan hubungan seksual $(\mathrm{p}=0,039)$ dan $\mathrm{r}=0,213$ artinya pendapatan berkorelasi lemah, sedangkan dengan jumlah anak $(\mathrm{p}=0,016)$ dan $\mathrm{r}=0,247$ artinya pendapatan dengan jumlah anak berkorelasi lemah. Nilai anak berhubungan dengan umur pertama melakukan hubungan seksual dan jumlah anak. Umur pertama melakukan hubungan seksual berhubungan juga dengan jumlah anak. 


\section{Parameter Estimasi Model}

Berdasarkan hasil uji regresi linear variabel nilai anak diperoleh nilai $\mathrm{p}=0,028$, berarti ada pengaruh langsung nilai anak terhadap jumlah anak, sedangkan umur istri dan pendapatan keluarga tidak berpengaruh langsung terhadap jumlah anak. Besar pengaruh secara keseluruhan terhadap jumlah anak sebesar 4,1\%, sedangkan sisanya 95,9\% dipengaruhi variabel lain seperti pendidikan, pekerjaan ibu dan suku.

Tabel 4. Pengaruh Langsung Umur Istri, Pendapatan Keluarga dan Nilai Anak terhadap Jumlah Anak

\begin{tabular}{lccc}
\hline \multicolumn{1}{c}{ Variabel } & B & $\boldsymbol{p}$ & $\boldsymbol{R}^{2}$ \\
\hline Umur istri & 0,077 & 0,461 & \\
Pendapatan keluarga & 0,202 & 0,051 & 0,041 \\
Nilai anak & $-0,226$ & 0,028 &
\end{tabular}

Berdasarkan Tabel 5 diperoleh bahwa umur istri $(\mathrm{p}<0,001)$ dan umur pertama melakukan hubungan seksual $(\mathrm{p}<0,001)$ berpengaruh secara tidak langsung terhadap jumlah anak. Besar pengaruh secara keseluruhan terhadap jumlah anak melalui umur pertama melakukan hubungan seksual sebesar 55,9\%, sedangkan sisanya 44,1\% dipengaruhi variabel lain seperti penggunaan alat kontrasepsi.

Tabel 5. Pengaruh Tidak Langsung Umur Istri, Pendapatan Keluarga dan Nilai Anak Terhadap Jumlah Anak Melalui Umur Pertama Melakukan Hubungan Seksual

\begin{tabular}{lccc}
\hline \multicolumn{1}{c}{ Variabel } & B & $\boldsymbol{p}$ & $\boldsymbol{R}^{2}$ \\
\hline Umur istri & 0,722 & $<0,001$ & \\
Pendapatan keluarga & 0,106 & 0,314 & \\
Nilai anak & 0,180 & 0,084 & 0,559 \\
Umur pertama & $-0,272$ & $<0,001$ & \\
melakukan hubungan & & & \\
Seksual & & & \\
\hline
\end{tabular}

Berdasarkan kedua model persamaan struktural di atas, kedua model tersebut memiliki makna yaitu : semakin tinggi nilai anak, maka semakin rendah umur pertama melakukan hubungan seksual. Umur pertama melakukan hubungan seksual dipengaruhi oleh umur istri sebesar 7,7\%, pendapatan keluarga sebesar 20,2\% dan nilai anak sebesar 22,6\%, sedangkan sebesar $95,9 \%$ dipengaruhi oleh faktor lain diluar model. 
Jumlah anak sebesar 72,2\% dipengaruhi oleh umur istri, sebesar 10,6\% dipengaruhi oleh pendapatan keluarga, nilai anak sebesar 18,0\% dan sebesar 27,2\% dipengaruhi oleh umur pertama melakukan hubungan seksual, sedangkan sebesar 44,1\% dipengaruhi oleh faktor lain diluar model.

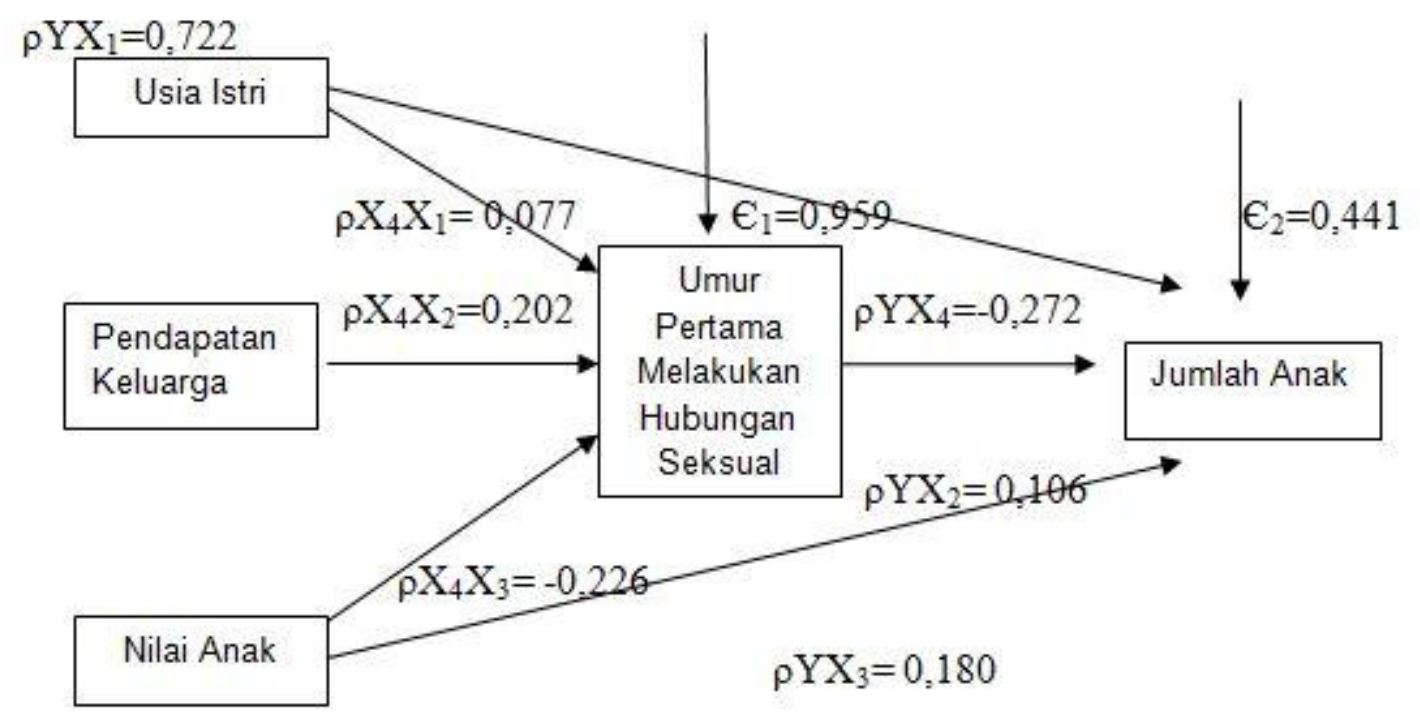

Gambar 1. Diagram Jalur Faktor - faktor yang Memengaruhi Jumlah Anak di Desa Pusong Kecamatan Banda Sakti Kota Lhokseumawe

\section{Pembahasan}

1. Pengaruh Umur Istri, Pendapatan Keluarga dan Nilai Anak Terhadap Umur Pertama Melakukan Hubungan Seksual di Desa Pusong Kecamatan Banda Sakti Kota Lhokseumawe

Berdasarkan hasil uji analisis regresi bahwa usia istri dan pendapatan keluarga tidak berpengaruh terhadap melakukan hubungan seksual pertama, sedangkan nilai anak berpengaruh terhadap melakukan hubungan seksual pertama. Besaran pengaruh simultan adalah 0,041 atau 4,1\% merupakan kontribusi dari variabel usia istri, pendapatan keluarga, dan nilai anak terhadap umur melakukan hubungan seksual pertama, sedangkan sisanya 95,9\% dipengaruhi faktor lai di luar model.

Melakukan hubungan seksual pertama merupakan salah suatu aktivitas individu. Aktivitas individu umumnya akan terkait pada suatu tujuan yang ingin dicapai oleh individu yang bersangkutan, demikian pula dalam hal perkawinan. Karena melakukan hubungan seksual pertama merupakan suatu aktivitas dari satu pasangan, maka sudah selayaknya merekapun juga mempunyai tujuan tertentu. Tetapi karena melakukan 
hubungan seksual pertama itu terdiri dari dua individu, maka adanya kemungkinan bahwa tujuan mereka itu tidak sama. Bila hal tersebut terjadi, maka tujuan itu harus dibulatkan agar terdapat suatu kesatuan dalam tujuan tersebut (Walgito, 2004).

Hasil penelitian menunjukkan bahwa rata-rata usia melakukan hubungan seksual pertama istri PUS di Desa Pusong Kecamatan Banda Sakti Kota Lhokseumawe berusia 21 tahun, hal ini dipengaruhi oleh budaya Aceh yang didalamnya terkandung nilai anak. Dari hasil penelitian didapatkan penyebab banyaknya perempuan melakukan hubungan seksual pertama di usia yang cukup muda adalah karena ada pengaruh budaya yang berkembang di masyarakat bahwa anak perempuan itu harus segera dinikahkan agar tidak menjadi perawan tua. Apabila anak perempuannya tidak segera menikah itu akan memalukan keluarga, dengan tidak memandang usia atau status pernikahan kebanyakan orang tua menerima lamaran tersebut karena menganggap masa depan anak akan lebih baik dan keluarga diharapkan bisa mengurangi beban orang tua. Ada juga anggapan bahwa anak gadisnya yang telah dewasa, tetapi belum berkeluarga, akan dipandang“aib” bagi keluarga, upaya untuk mengatasi hal tersebut ialah menikahkan anak gadis yang dimilikinya secepat mungkin sehingga pada usia muda banyak yang sudah melakukan hubungan seksual pertama.

Hal ini juga didukung dari pendidikan ibu yaitu semakin tinggi pendidikan seseorang akan semakin lama usia melakukan hubungan seksual pertama karena wanita usia subur beranggapan bahwa butuh kesiapan yang matang dalam ikatan pernikahan, bahkan akan lebih tahu lagi bahaya kehamilan pada usia di bawah umur 20 tahun dan di atas umur 35 tahun yang berisiko terhadap kematian bayi dan ibu. Tetapi ada Orang tua yang ingin anaknya putus sekolah dan lebih baik menikah. Ini disebabkan kegiatan anak hanya jalan-jalan atau bertemu dengan kawan-kawannya. Kasus kehamilan sebelum menikah yang banyak terjadi yang mengakibatkan orang tua merasa was-was dan takut kalau terjadi pada anaknya. Oleh karena itu orang tua yang anaknya sudah memiliki pasangan dan merasa cocok segera dinikahkan walaupun usianya masih belum dewasa. Hal ini disebabkan karena orang tua tidak mau menanggung malu jika anaknya melakukan hubungan seksual dan hamil sebelum menikah.

Umur melakukan hubungan seksual pertama dini sering dijumpai di daerah-daerah miskin atau di daerah pedesaan. Keterbatasan ekonomi dan rendahnya penghasilan menyebabkan orang tua jarang menyekolahkan anaknya sampai ketingkat yang lebih 
tinggi. Orang tua berusaha untuk dapat memenuhi kebutuhan keluarganya, sehingga orang tua jarang mendorong anaknya untuk terus bersekolah. Sama halnya dengan kenyataan yang ada di masyarakat bahwa status ekonomi orang merupakan menjadi alasan sebagian besar responden menyebabkan terjadinya menikah pada usia muda. Rendahnya pendapatan keluarga sehingga tidak dapat menyekolahkan anaknya lebih lanjut. Kondisi tersebut membuat anak merasa membebani orang tua dan tidak mau melanjutkan sekolahnya sehingga memutuskan untuk menikah dini.

2. Pengaruh Umur Istri, Pendapatan Keluarga, Nilai Anak dan Umur Pertama Melakukan Hubungan Seksual Terhadap Jumlah Anak di Desa Pusong Kecamatan Banda Sakti Kota Lhokseumawe

Berdasarkan hasil uji analisis regresi bahwa usia istri, nilai anak, dan umur pertama melakukan hubungan seksual berpengaruh terhadap jumlah anak, sedangkan pendapatan tidak berpengaruh terhadap jumlah anak. Besaran pengaruh simultan adalah 0,559 atau 55,9\% merupakan kontribusi dari variabel usia istri, pendapatan keluarga, nilai anak dan umur pertama melakukan hubungan seksual terhadap jumlah anak di Desa Pusong, sedangkan sisanya 44,1\% dipengaruhi faktor lain di luar model.

Usia istri mempengaruhi jumlah anak, semakin tua umur istri saat ini maka semakin banyak jumlah anak yang dimiliki hasil ini menunjukkan hubungan yang positif. Hal ini juga sejalan menurut Muchtar dan Purnomo (2009), bahwa pada umumnya semakin tua umur wanita, maka semakin banyak jumlah anak yang dilahirkan. Dari hasil penelitian Muchtar dan Purnomo (2009) diketahui bahwa terdapat hubungan antara umur wanita dengan tingkat kelahiran menunjukkan hubungan positip, yakni semakin tua umur semakin banyak kelahiran. Ibu berumur di bawah 24 tahun memiliki rata-rata anak lahir hidup satu anak, sedangkan ibu berumur 35-39 tahun rata-rata anak lahirhidup 3 anak, dan meningkat menjadi 4 anak pada ibu berumur di atas 45 tahun.

Meningkatnya usia dalam melakukan hubungan seksual pertama ibu disebabkan oleh berbagai kemungkinan seperti meningkatnya jenjang pendidikan, meningkatnya penerimaan informasi dari berbagai media massa, dan usaha meningkatkan pengembangan pekerjaan dan karir. Dengan demikian, semakin tingginya tingkat pendidikan, maka semakin mudah pula dalam menerima berbagai informasi dan pengetahuan yang berkaitan dengan jumlah anak. 
Nilai anak akan memengaruhi keputusan orang tua untuk menentukan jumlah anak yang diinginkan, nilai anak seperti mengharuskan punya anak laki-laki akan membuat seorang cenderung untuk memiliki anak laki-laki. nilai anak yang menyatakan bahwa anak akan bermanfaat dalam membantu pekerjaan orang tua, dapat membantu keuangan keluarga dan membantu merawat orang tuanya saat sakit akan meningkatkan kecenderungan seseorang untuk memiliki banyak anak. Ada tiga macam kegunaan anak, yaitu: 1) sebagai suatu barang konsumsi, misalnya sebagai sumber hiburan, 2) sebagai suatu sarana produksi, yakni anak diharapkan untuk melakukan suatu pekerjaan tertentu yang menambah pendapatan keluarga, 3) sebagai sumber ketenteraman, baik pada hari tua maupun sebaliknya. Di negara berkembang anak dianggap sebagai barang investasi atau aktivitas ekonomi, yaitu orang tua berharap kelak menerima manfaat ekonomi dari anak.

Di daerah pedesaan anak mempunyai nilai yang tinggi bagi keluarga. Anak dapat memberikan kebahagiaan kepada orang tuanya selain itu akan merupakan jaminan di hari tua dan dapat membantu ekonomi keluarga, banyak masyarakat di desa di Indonesia yang berpandangan bahwa banyak anak banyak rejeki. Keluarga-keluarga yang tinggal di pedesaan mempunyai anak yang banyak dengan alasan bahwa anak memberikan keuntungan ekonomi dan rasa aman bagi keluarganya.

Pada status perkawinan yang stabil maka semakin rendah umur pertama melakukan hubungan seksual, semakin panjang waktu yang terpakai dalam proses reproduksinya. Oleh karena itu, orang yang melakukan hubungan seksual pertama di usia muda akan lebih banyak melahirkan anak. Pada masa klimaks, keluarga yang memiliki anak banyak akan mempertimbangkan keuntungan dan kerugian memiliki anak.

Hasil penelitian menunjukkan terdapat pengaruh umur melakukan hubungan seksual pertama dengan jumlah anak. Semakin muda usia ibu melakukan hubungan seksual pertama maka semakin banyak jumlah anak yang dilahirkan, hal ini menunjukkan hubungan negatif antara melakukan hubungan seksual pertama dengan jumlah anak. Umur kawin pertama dapat menjadi indikator dimulainya seorang perempuan berpeluang untuk hamil dan melahirkan. Perempuan yang melakukan hubungan seksual pertama usia muda mempunyai rentang waktu untuk hamil dan melahirkan lebih panjang dibandingkan dengan mereka yang kawin pada umur lebih tua dan mempunyai lebih banyak anak. Peningkatan rata-rata usia melakukan hubungan seksual pertama dan jumlah wanita yang masih lajang berhubungan erat dengan penurunan fertilitas. Wanita yang menunda 
melakukan hubungan seksual pertama akan mempunyai rata-rata jumlah anak yang lebih sedikit.

Sebagian besar orang tua menginginkan anak dalam jumlah sedang (3-5 orang anak). Hal ini sejalan dengan BkkbN yang menyatakan bahwa untuk menuju keluarga yang bahagia, sejahtera dan berkualitas tidak perlu membentuk keluarga besar dengan jumlah anak yang banyak, jika tidak mampu memenuhi kebutuhan keluarga. Kebutuhan keluarga tidak hanya kebutuhan pangan, namun terdapat kebutuhan lain seperti sandang, perumahan, pendidikan, kesehatan dan kebutuhan masa depan anak. Kondisi perubahan jumlah anak yang diinginkan saat ini menunjukkan telah adanya pergeseran nilai yang dianut pada keluarga pascasosialisasi KB. Fakta ini juga menunjukkan bahwa keluarga saat ini, meskipun di perdesaan, menjawab kelemahan sumber daya yang mereka miliki dengan membatasi jumlah anak menjadi lebih sedikit dari generasi sebelumnya.

\section{Keterbatasan Penelitian}

1. Penelitian ini merupakan penelitian observasional dengan pendekatan cross sectional dimana pengambilan data dilakukan hanya satu kali secara bersamaan. Oleh sebab itu penelitian ini tidak bermaksud melihat hubungan sebab akibat antara variabel independen dengan variabel dependen hanya memberikan informasi tentang pengaruh antara variabel independen terhadap variabel dependen melalui variabel intervening/perantara.

2. Pengukuran variabel dalam analisis jalur paling tidak berupa skala interval atau yang paling baik skala rasio. Variabel terdiri paling sedikit 4 nilai. Jadi, apabila menggunakan skala Likert lebih baik dipergunakan skala minimal 5 butir. Oleh karena dalam penelitian ini terdapat nilai variabel jumlah anak 0 dan 4 skala Likert variabel nilai anak, maka hasil analisis jalur tidak memadai dan kurang stabil.

3. Sampel dalam analisis jalur minimal 100 responden atau paling sedikit harus 5 kali banyaknya parameter yang akan diperkirakan, bahkan untuk menghasilkan analisis yang stabil membutuhkan sampel lebih dari 5000 responden. Oleh karena sampel dalam penelitian ini 95 responden atau dibawah dari 100 responden, maka hasil analisis jalur kurang stabil. 


\section{KESIMPULAN}

1. Besarnya pengaruh umur istri, pendapatan keluarga dan nilai anak terhadap umur pertama melakukan hubungan seksual sebesar 10,4\% dan hanya 89,6\% dipengaruhi faktor lain seperti pendidikan dan pekerjaan istri.

2. Besarnya pengaruh umur istri, pendapatan keluarga, nilai anak terhadap jumlah anak melalui umur pertama melakukan hubungan seksual sebesar 59,3\% dan sebesar 40,7\% dipengaruhi oleh faktor lain seperti penggunaan alat kontrasepsi.

3. Umur istri berpengaruh lebih besar terhadap jumlah anak melalui umur pertama melakukan hubungan seksual. Jika semakin tua umur istri maka semakin banyak jumlah anak yang dilahirkan dan sebaliknya. Umur pertama melakukan hubungan seksual pada umur muda memiliki masa reproduksi yang panjang, sehingga kemungkinan mempunyai anak yang banyak.

\section{SARAN}

1. Kepada tokoh masyarakat dan tokoh agama desa pusong kota lhokseumawe sebagai ketua "tuha peut gampong" agar dapat meluruskan pemahaman negatif tentang penggunaan alat kontrasepsi sehingga masyarakat yakin bahwa alat kontrasepsi halal / dapat digunakan oleh istri pasangan usia subur guna mengatur jumlah anaknya.

2. Bagi Dinas Kesehatan Kota Lhokseumawe khususnya BkkbN agar meningkatkan promosi kesehatan kepada PUS (Pasangan Usia Subur) untuk mensosialisasikan program-program Keluarga Berencana melalui tokoh agama sebagai panutan masyarakat aceh pada umumnya dan pusong khususnya agar kemungkinan anak yang lahir pun akan terminimalisir oleh karna penggunaan alat kontrasepsi.

3. Bagi istri pasangan usia subur agar lebih aktif mencari informasi melalui media cetak, media informasi, media elektronik tentang manfaat jumlah anak yang ideal dalam keluarga, dapat juga dengan cara meningkatkan pendidikan atau meningkatkan karir saat bekerja sehingga diharapkan dengan pengetahuan yang tinggi dalam mengambil keputusan memiliki jumlah anak yg sedikit guna mencapai keluarga kecil sehat, bahagia dan sejahtera. 


\section{DAFTAR PUSTAKA}

Badan Pusat Statistik (BPS), BKKBN, Depkes RI, Macro Internasional, 2013. Indonesia Demographic and Health Survey 2012, Calverton, Maryland, USA : BPS dan Macro Internasional.

Siregar, RY., 2011, Faktor yang Mendasari Penentuan Jarak Kehamilan Pada Pasangan Usia Subur (PUS) di RB. Mahdarina, Padang Bulan. http://repository.usu.ac.id/bitstream/123456789/23957/4/Chapter\%20II.pdf [diunduh pada tanggal 21 Februari 2014]

Dinkes Aceh, 2011, Profil Kesehatan Provinsi Nanggroe Aceh Darussalam Tahun 2011, Banda Aceh

Dinkes Lhokseumawe, 2012, Profil Dinas Kesehatan Kota Lhokseumawe Tahun 2012, Lhokseumawe

Muchtar, R \& Purnomo, E., 2009, Proximate Determinant Fertilitas di Indonesia, Puslitbang KB dan Kesehatan Reproduksi Badan Koordinasi Keluarga Berencana Nasional, Jakarta

Walgito, B., 2004. Pengantar Psikologi Umum. Jakarta. Erlangga. 